\title{
Apendiks Tümörlerinin İnsidansı, Tedavisi ve Sağ Kalım: Retrospektif Bir Çalıșma
}

\author{
$\underline{\text { Servet KOCAÖZ }}{ }^{1}$, Emin GEMCIOĞLU ${ }^{2}$, Abdurrezzak YILMAZ ${ }^{2}$, Aydan KILIÇARSLAN $^{3}$, Ömer PARLAK ${ }^{4}$
}

\section{Öz}

$\mathrm{Bu}$ araştırma, appendektomi sırasında alınan numunelerden elde edilen sonuçlara göre tümörlerin klinik ve patolojik özelliklerini ve insidanslarını belirlemek, tanılama sonrasında yapılan tedavileri ve hastaların sağ kalım sürelerini değerlendirmek amacıyla yapılmıştır. Retrospektif olarak yapılan bu araştırmanın verileri, 2007-2017 yılları arasında Ankara Atatürk Eğitim ve Araştırma Hastanesi'nde akut apandisit ön tanısıyla opere edilen 4813 hastanın dosyasından elde edilmiştir. Appendektomi yapılan hastaların 15 (\%0,31)'inde appendiks tümörü olduğu saptanmıștır. Bu hastaların tümörlerinin histopatolojik sınıflandırmaya göre 8'inde karsinoid tümör, 6'sında müsinöz adenokarsinom ve 1'inde adenokarsinom olduğu belirlenmiştir. Karsinoid tümörlü hastaların yaş ortalaması 30,29 $\pm 7,95$, müsinöz adenokarsinomlu hastaların yaş ortalaması $65 \pm 18,81$ olarak saptand1. Kadınlarda erkeklere göre iki kat daha fazla appendiks tümörünün geliştiği tespit edilmiştir. Tümör çap1 $1 \mathrm{~cm}$ 'den küçük olan 9 hastaya sadece appendektomi operasyonu yapılmış ve takipleri sonrasında tümörlerin nüks etmediği belirlenmiştir. Postoperatif mezoappendiks tutulumu olan 3 hastaya, ikinci operasyonda sağ hemikolektomi yapılmıştır. Ameliyat öncesi çekilen bilgisayarlı tomografide, 3 hastada periapendiküler kitle tespit edildi. Maligniteden şüphelenilen bu üç hastaya sağ hemikolektominin yanı sıra omentektomi, peritonektomi ve lenf nodu diseksiyonu operasyonu gerçekleştirilmiştir. Hastaların beş yıllık yaşam süresi kasinoid tümörü olanlarda \%100 iken, müsinöz adeno karsinomlarda \%67 olduğu saptanmıştır. Sonuç olarak, araştırmamızda kadınlarda erkeklere göre daha fazla görüldüğü saptanan appendiks tümörlerinin çoğunluğu rastlantısal olarak tespit edilmiştir. Karsinoid tümörlü olan hastaların prognozu ve hayatta kalım oranları, müsinöz adeno karsinomlulara göre daha iyi olduğu belirlenmiştir. Bu nedenle appendiks tümörün histopatolojik incelemesi sonrasında elde edilen rapora göre hastaların takibinin ve tedavisinin yapılması önemlidir.

Anahtar Kelimeler: Appendiks tümörü, insidans, histopatoloji, karsinoid tümör, müsinöz adenokarsinom, sağ kalım
Gönderi Tarihi: 2711.2018

Kabul Tarihi: 27.02.2019

Online Yayın Tarihi: 31.12.2019

DOI: $10.26453 /$ otjhs.487941

Sorumlu Yazar

Servet KOCAÖZ

General Surgery Specialist, Department of General Surgery, Ankara Atatürk Eğitim ve Araştırma Hastanesi Üniversiteler mah. Bilkent cad., No:1, 06800 Çankaya, Ankara, Turkey. Tel: +90 (0312) 2912525

Fax:+90 (0312) 2912525

E Mail: servet.kocaoz@gmail.com

.


Key Words: Appendix tumor, incidence, histopathology, carcinoid tumor, mucinous

adenocarcinoma, survival

\footnotetext{
${ }^{1}$ Department of General Surgery, Atatürk Training and Research Hospital, Bilkent, Ankara, Turkey.

${ }^{2}$ Department of Internal Medicine, Atatürk Training and Research Hospital, Bilkent, Ankara, Turkey.

${ }^{3}$ Department of Medical Pathology, Faculty of Medicine, Ankara Yıldırım Beyazıt University, Bilkent, Ankara, Turkey

${ }^{4}$ Department of General Surgery, Faculty of Medicine, Ankara Yıldırım Beyazıt University, Bilkent, Ankara, Turkey
}

\section{INTRODUCTION}

Appendiceal tumors are rarely seen in the gastrointestinal system. ${ }^{1}$ It is declared that the incidence of appendiceal tumors is less than $0.5 \%$ between all gastrointestinal system malignancies. It is also emphasized that the age-adjusted incidence rate of appendiceal tumors is only 0.12 cases per million per year. ${ }^{2}$ Appendix tumors are classified as adenocarcinomas, mucinous tumors, carcinoids, goblet cell carcinoids, and signet ring cell tumors according to colonic types. ${ }^{2,3}$ Carcinoids are the most prevalent type of appendix tumors. Appendix tumors may show other inflammatory reactions like acute pain in the lower right quadrant, fever, leukocytosis, and similar acute appendicitis signs. Therefore, appendiceal tumors may occur with periappendicular mass dependent to acute appendicitis findings or appendicitis rupture. ${ }^{4}$ Appendiceal mass can be detected in $2.0-6.0 \%$ of the examined patients with a diagnosis of acute appendicitis. ${ }^{5}$ Most of these tumors after appendectomy are detected after histopathological examination. ${ }^{4,6}$ It is declared that $0.9 \%-1.7 \%$ of the tissue samples of patients who were taken for operation due to acute appendicitis were found to have malignancy ${ }^{7,8}$ and the incidence of cancer is increased up to $5.9 \%$ to $12.0 \%$ in patients with inflammatory appendiceal mass. ${ }^{9,10}$

Appendectomy is used as a standard treatment method in uncomplicated cases of acute appendicitis. However, patients with some appendiceal tumors cannot benefit from surgical treatment. ${ }^{11}$ Medical treatment of acute appendicitis may increase the likelihood of delaying the diagnosis of appendiceal tumors. ${ }^{12}$ Since appendiceal tumors are rare, no clear decision has been made as to whether to perform interval appendectomy. ${ }^{11}$ Appendiceal cancer patients whose tumor characteristics are determined according to pathology reports can be performed in an operation with secondary surgery. ${ }^{13}$

In addition, the type of the treatment and the survival rates of patients may vary according to the size and involvement of the appendiceal tumor. Histopathologic 
features, size, and differences in the spreading stage of the tumor are important for the determination of treatment protocols for patients with the appendiceal tumor. This study was carried out to determine the clinical and pathological features and incidences of benign and malign tumors according to the results obtained from the samples taken during an appendectomy and to evaluate the treatment methods and survival time of the patients after the diagnosis.

\section{MATERIALS AND METHODS}

In this retrospective study, the files of 4813 patients taken for appendectomy operation with the diagnosis of acute appendicitis between the years of 2007-2017 at Ankara Atatürk Training and Research Hospital were examined. Data were collected regarding the age, sex, histopathologic type of tumor, location and size of the tumor, type of operation performed, secondary operations, whether or not chemotherapy was taken, and survival time from the files of all the patients included in the study. The survival time of the patients was calculated according to five years.

During an appendectomy, appendiceal materials taken from all patients were evaluated and diagnosed by expert pathologists. According to the pathologic results, tumor types of patients who found benign and malign appendiceal cancer were separated as carcinoid tumor, adenocarcinoma, mixt carcinoid adenocarcinoma, differentiated mucinous adenocarcinoma, and undifferentiated mucinous adenocarcinoma.

\section{Ethical Consideration}

After the written permission of the Atatürk Training and Research Hospital, the study was submitted to the ethics committee. Y1ldırım Beyazıt University Faculty of Medicine Clinical Trials Ethics Review Commission (decision dated 91, 16 April 2018) started to work.

\section{Statistical analysis}

Data were analyzed by using SPSS program. (version 16; SPSS, Chicago, IL, USA). In the evaluation of descriptive statistics, number, percentage, mean, standard deviation values were used.

\section{RESULTS}

In our study, $15(0.31 \%)$ of 4813 patients who underwent appendectomy between 2007-2017 were determined to have appendix tumor. In total, 8 (53.3\%) carcinoid tumors were found in appendix including carcinoid tumor in 7 patients and mixt carcinoid adenocarcinoma in one patient. In addition, $46.7 \%$ of malign appendiceal tumors are mucinous 
adenocarcinomas. In the patients included in the study, the mean age of the male was $38.0 \pm 1.54$, while that of the female was $54.2 \pm 2.48$. It has been determined that malign appendiceal tumors are seen twice as often in females as males. The mean age of the patients with carcinoid tumor was $30.29 \pm 7.95$ and the mean age of the patients with mucinous adenocarcinoma was $65 \pm 18.81$. While carcinoid tumors are seen in women under 30 year's age, mucinous adenocarcinomas are mostly developed in those over 60 years age old. Half of the males in the $30-60$ age group were detected to have carcinoid tumor and the other undifferentiated mucinous adenocarcinoma. Only one of the males was found to have a mixt carcinoma after 60 years of age. A carcinoid tumor was detected in all patients below 30 years of age with an appendix tumor (Table 1).

In Table 2, the distribution localization and size of appendiceal tumor types were seen. In $60 \%$ of appendiceal tumors, only mucosal involvement was observed while $26.7 \%$ of them were involved in the mesoappendix region. The tumor size was less than $1 \mathrm{~cm}$ in $60.0 \%$ of patients with appendiceal tumor. The majority $(75.0 \%)$ were determined to be smaller than $1 \mathrm{~cm}$ in size, while five of the carcinoid tumors showed mucosal localization (Figure 1A-
1B). All of the tumors with mesoappendix location were found to be larger than $2 \mathrm{~cm}$ in size (Table 2). Only one of the patients with mucinous adenocarcinoma could be diagnosed in the carcinoma in situ stages. A patient with mixt carcinoid adenocarcinoma was found to be $30 \%$ of Ki67 index and a tumor diameter of 2.5 $\mathrm{cm}$. This carcinoma was stained diffuse with keratin 20, focal with keratin 7 , widespread with chromogranin, focal with synaptophysin, and focal positive with p53 (Figure 2A-2B). A 63-year-old male patient had undergone right hemicolectomy in the second operation 1 month after an appendectomy. As a result of the pathology following the second operation, the focal tumor was detected in the appendix and the patient was given 6 cycles of chemotherapy.

The distribution performed surgical treatments of benign and malign appendiceal tumor types is given in Table 3. All patients with carcinoid tumors (100.0\%) were performed appendectomy operation. Appendectomy was performed with complementary right hemicolectomy to the patient with mixt carcinoid adenocarcinoma and chemotherapy was applied after the operations. One of the patients with undifferentiated mucinous adenocarcinoma was carcinoma in situ, 
and only appendectomy was performed. The other patient underwent right hemicolectomy, omentectomy and peritonectomy in the second operation. Right hemicolectomy, omentectomy, total abdominal hysterectomy, bilateral salpingo-oophorectomy $(\mathrm{TAH}+\mathrm{BSO})$ were performed in 2 patients with differentiated mucinous adenocarcinoma and 1 patient with adenocarcinoma (according to the findings obtained from tomography) in the first operation (Figure 3). All three of these patients were made node dissection and peritonectomy during surgeries and chemotherapy with Eloxatin was performed postoperatively. A patient with differentiated mucinous adenocarcinoma and a tumor with a diameter of $0.5 \mathrm{~cm}$ was performed to secondary right hemicolectomy and chemotherapy was given after surgery. This patient underwent surgery for TAH + BSO, omentectomy, peritonectomy, and lymph node dissection due to ovarian tumor development after 21 months of surgical treatment. No fatal complications such as anastomotic leak due to the operation performed were observed after surgery applied to all patients. Only wound infection was seen in one patient. Seven $(100.0 \%)$ of carcinoid tumor patients completed 5 years of life. No recurrence has been found. Our patient, who had mixt carcinoid adenocarcinomas, lost his life due to the concomitant cardiac disease at 7 years, although no recurrence was observed during his follow-up. Four $(66.7 \%)$ of patients with mucinous cell adenocarcinoma were able to complete the 5-year survival period. One patient who was diagnosed with adenocarcinoma at the age of 80 years died of cardiac problems 5 months after the operation while receiving chemotherapy. A 36-year-old patient with undifferentiated mucinous carcinoma and a tumor $0.5 \mathrm{~cm}$ in diameter died 10 months after surgery and 1 month after 6 cycles of chemotherapy treatment due to a lung infection.

\section{DISCUSSION}

Although the incidence of appendiceal tumors increases day by day, it is still rare among gastrointestinal system cancers. In a study using The Surveillance, Epidemiology, and End Results (SEER) data, it has been reported that the incidence of appendiceal cancer increased by $54.0 \%$ from $2000(0.63 \%)$ to $2009(0.97 \%) .{ }^{14}$ The incidence of appendiceal tumors in our study was found to be 0.31 (Table 1). In the studies carried out by Schwartz, et al. ${ }^{6}$, the incidence of appendiceal cancer was $1.7 \%$ in the samples taken from the appendectomy operation of 1793 patients with acute and chronic appendicitis. In a 
systematic review, it was reported that $0.9 \%$ to $1.4 \%$ of patients undergoing appendectomy for acute appendicitis had malign tumors. ${ }^{15}$ In a study conducted in our country, it was reported that the incidence of premalignant lesions and malign neoplasms in samples taken after appendectomy were 0.5 and 0.6, respectively. ${ }^{16}$ In our study, the incidence of the malign appendiceal tumor was found to be quite low compared to other studies. ${ }^{6,14-16}$ These results obtained from our study is thought to be due to the fact that the population to be studied is younger and has different characteristics such as genetics and nutrition.

Studies have reported that appendiceal tumor detection rates in patients with a periappendicular mass up to $6.0-12.0 \% .^{9,15}$ In our study, $45(0.9 \%)$ of the appendectomy patients were found to have an appendiceal inflammatory mass (plastron appendicitis). Interval appendectomy was performed in these patients who were treated conservatively, 6-8 weeks later. Appendiceal tumors were detected in three of these patients $(6.7 \%)$. This finding in our study is consistent with the literature. ${ }^{9,15}$

The most common type of appendiceal tumor is the carcinoid tumor. ${ }^{4}$ It is reported that the incidence of carcinoid tumors seen in $60.0 \%$ of appendix tumors varies between $0.30-2.27 \% .^{18-20}$ It has been emphasized that $70.0-95.0 \%$ of carcinoid tumors are smaller than $1 \mathrm{~cm}$ in size and make virtually no metastases and can only be treated with the simple appendectomy. ${ }^{18}$ It is also expressed that carcinoid tumors are seen at earlier ages, compared to noncarcinoids, and in females than males. ${ }^{6,21}$ Right hemicolectomy should be performed in patients with carcinoid tumors larger than $2 \mathrm{~cm}^{18-20}$ In our study, $75.0 \%$ of carcinoid tumors were determined to be smaller than $1 \mathrm{~cm}$, and the majority were detected in women and in persons younger than 30 years (Table 1 and 2). As indicated by the literature ${ }^{18-20}$, in our carcinoid patients without mesoappendix involvement less than $2 \mathrm{~cm}$ in our study, the only appendectomy is sufficient for treatment. All patients with carcinoid tumor were undergone appendectomy surgery alone, and with a tumor greater than $2 \mathrm{~cm}$ in size and with a mixt carcinoid adenocarcinoma, right hemicolectomy was performed (Table 3) and our results have been consistent with the literature. ${ }^{6,18-21}$ In patients with carcinoid tumors, the risk of perineural and lymphovascular invasion was reported as $20 \%$ in patients with a tumor diameter between $1-2 \mathrm{~cm}$. It has been reported that the risk of metastasis increases in patients with $\mathrm{Ki}-67$ 
proliferation index greater than $2 \%$. Therefore, prophylactic complementary right hemicolectomy is recommended for patients with mesoappendix involvement. $^{15,22}$

Well-differentiated carcinoid tumors consist of two subtypes. Enterochromaffin (EC) cell tumors produce Serotonin and Substance P, whereas tubular variation of carcinoid produces Enteroglucagon or Neuropeptide Y (L) cell. Carcinoid syndrome occurs when the hormones secreted by carcinoid tumors are mixed into the systemic circulation. After liver metastasis, hormones that are not metabolized in the liver and secreted into the system cause symptoms. In our study, no cases with carcinoid syndrome developed in our patients. ${ }^{15}$

Adenocarcinomas are rarely diagnosed tumors of appendix before the operation. ${ }^{4}$ For all types of adenocarcinoma, right hemicolectomy is recommended for surgical management. ${ }^{4,23}$ It is stated that the rate of invasion and the lymph nodule metastasis of adenocarcinomas is high and that adjuvant chemotherapy should be applied if lymphatic involvement is present. $^{24}$ In our study, adenocarcinoma was detected in a patient over 60 years old $(6.7 \%)$ in mesoappendix and $3.5 \mathrm{~cm}$ in size. Right hemicolectomy underwent on this patient, chemotherapy was applied after surgery, but he lost his life due to cardiac disorder after 5 months.

Mucocele, which can be seen as nonneoplastic and neoplastic, causes enlargement of the appendix and filling with mucocele is seen in $0.2-0.7 \%$ of appendiceal pathologies. ${ }^{25,26}$ There are four kinds of mucocele histopathologically. These; retention cysts, epithelial hyperplasia, mucinous cystadenoma, and mucinous cystadenocarcinoma. ${ }^{27}$ Mucinous adenocarcinomas, which are very common appendiceal malign tumors causing $5.0 \%$ of mucoceles, are more widespread in females than males and ages range from $62-66 .^{26}$ In our study, it was found that mucinous adenocarcinoma was observed in $0.12 \%$ of the patients who received appendectomy and developed two times more in females than males. In our study, it was also determined that differentiated adenocarcinomas were detected only in females and over 60 years of age. However, undifferentiated mucinous adenocarcinomas were found only in males (Table 1).

In the literature, mucinous cysts adenocarcinomas are reported to be 32.0$58.0 \%$ for those with low-grade 5-year survival rates and $23.0 \%$ for those with high grades. $^{26}$ In our study, it was 
determined that the 5-year survival rate of patients with mucinous adenocarcinoma was $66.7 \%$. In our study, the survival rate in patients with mucinous adenocarcinoma was high, and the size of the tumor determined in four patients was less than 2 cm. In addition, omentectomy, peritonectomy, lymph node dissection and early surgical intervention of all patients increased the survival rate.

\section{Conclusion}

Since the majority of appendiceal tumors are incidentally detected, it is very important to follow histological reports after an appendectomy. The low average age, genetic characteristics and nutritional habits of appendectomy patients, frequent use of diagnostic laparotomy and routine application of interval appendectomy are thought to affect the incidence of appendiceal tumors and survival rates. In our study, the incidence of appendiceal tumors $(0.31 \%)$ was significantly lower in patients undergoing appendectomy than in other studies. It has been determined that these tumors are seen more often in females than males. It has been determined that only appendectomy is sufficient for patients with carcinoid tumors less than 2 $\mathrm{cm}$ in diameter. In appendiceal tumors, initiation of treatment with good histopathologic diagnosis and staging is effective in the survival of patients. Routine omentectomy, peritonectomy and lymph node dissection have increased the survival rate in all patients and it is thought that rapid spread and recurrence are prevented in patients with adenocarcinoma.

\section{REFERENCES}

1. Shenoy S. Goblet cell carcinoids of the appendix: Tumor biology, mutations and management strategies. World $\mathbf{J}$ Gastrointest Surg. 2016;8(10):660-9.

2. McCusker ME, Coté TR, Clegg LX, Sobin LH. Primary malignant neoplasms of the appendix: a population-based study from the surveillance, epidemiology and endresults program, 1973-1998. Cancer. 2002;94(12):3307-12.

3. McGory ML, Maggard MA, Kang H, O'Connell JB, Ko CY. Malignancies of the appendix: beyond case series reports. Dis Colon Rectum. 2005;48:2264-71.

4. Ruoff C, Hanna L, Zhi W, Shahzad G, Gotlieb V, Saif MW. Cancer of appendix: Review of the literatures. ISRN Oncol. 2011;1-6.

5. Wright GP, Mater ME, Carroll JT, Choy JS, Chung MH. Is there truly an oncologic indication for interval appendectomy? Am J Surg. 2015;209:442-6. 
6. Schwartz JA, Forleiter C, Lee D, Kim GJ. Occult appendicieal neoplasms in acute and chronic appendicitis: A single-institution experience of 1793 appendectomies. Am Surg. 2017;83(12):1381-5.

7. Connor SJ, Hanna GB, Frizelle FA. Appendiceal tumors: retrospective clinicopathologic analysis of appendiceal tumors from 7,970 appendectomies. Dis Colon Rectum. 1998;41(1):75-80.

8. Marudanayagam R, Williams GT, Rees BI. Review of the pathological results of 2660 appendicectomy specimens. J Gastroenterol. 2006;41(8):745-9.

9. Deelder JD, Richir MC, Schoorl T, Schreurs WH. How to treat an appendiceal inflammatory mass: operatively or nonoperatively? J Gastrointest Surg. 2014;18:641-5.

10. Misdraji J. Appendiceal mucinous neoplasms: controversial issues. Arch Pathol Lab Med. 2010;134:864-70.

11. Santos D, Chiang YJ, Badgwell B. Appendicitis in cancer patients is often observed and can represent appendiceal malignancy. Am Surg. 2016;82(10):1028-32.

12. Loftus TJ, Raymond SL, Sarosi GA Jr, Croof CA, Smith RS, Efron PA, et al. Predicting appendiceal tumors among patients with appendicitis. J Trauma Acute Care Surg. 2017;82(4):771-5.

13. Ozcelik CK, Turanli S, Bozdogan N, Dibekoglu C. Clinical experience in appendiceal neuroendocrine neoplasms. Contemp Oncol (Pozn). 2015;19(5):410-3.

14. Marmor S, Portschy PR, Tuttle TM, Virnig BA. The rise in appendiceal cancer incidence: 2000-2009. J Gastrointest Surg. 2015;19(4):743-50.

15. Teixeira FJR Jr, Couto Netto SDD, Akaishi EH, Utiyama EM, Menegozzo CAM, Rocha MC. Acute appendicitis, inflammatory appendiceal mass and the risk of a hidden malignant tumor: a systematic review of the literature. World J Emerg Surg. 2017;12:12.

16. Bulut T, Arduçoğlu Merter A. The retrospective analysis of 2373 appendectomy specimens. F.Ü. Sağ. Bil Tip Derg. 2017;31(3):105-9.

17. Yilmaz M, Akbulut S, Kutluturk K, Sahin N, Arabaci E, Ara C, Yilmaz S. Unusual histopathological findings in appendectomy specimens from patients with suspected acute appendicitis. World J Gastroenterol. 2013;19(25):4015-22.

18. Shapiro R, Eldar S, Sadot E, Papa MZ, Zippel DB. Appendiceal carcinoid at a large tertiary center: pathologic findings and long-term follw-up 
evaluation. Am J Surg. 2011;201(6):805-8.

19. In't Hof $\mathrm{KH}$, van der Wal $\mathrm{HC}$, Kazemier G, Lange JF. Carcinoid tumors of the appendix: an analysis of 1,485 consecutive emergency appendectomies. J Gastrointest Surg. 2008;12(8):1436-8.

20. Ozer MT, Demirbas S, Celik E, Safali M, Harlak A, Coskun K, et al. Natural behaviour and surgical treatment of appendiceal carcinoids: an analysis of 2,376 consecutive emergency appendectomies. Bratisl Lek Listy. 2011;112(11):619-22.

21. Estrozi B, Bacchi CE. Neuroendocrine tumors involving the gastroenteropancreatic tract: a clinicopathological evaluation of 773 cases. Clinics (Sao Paulo). 2011;66(10):1671-5.

22. Goede AC, Caplin ME, Winslet MC. Carcinoid tumour of the appendix. $\mathrm{Br}$ J Surg. 2003 Nov;90(11):1317-22.

23. Benedix F, Reimer A, Gastinger I, Mroczkowski P, Lippert H, Kube R; Study Group. Primary appendiceal carcinoma--epidemiology, surgery and survival: results of a German multicenter study. Eur J Surg Oncol. 2010;36(6):763-71.

24. Nitecki SS, Wolf BG, Schlinkert R, Sarr MG. The natural history of surgically treated primary adenocarcinoma of the appendix. Ann Surg. 1994;219(1):51-7.

25. Orcutt ST, Anaya DA, Malafa M. Minimally invasive appendectomy for resection of appendiceal mucocele: Case series and review of the literature. Int J Surg Case Rep. 2017;37:13-6.

26. Rymer B, Forsythe RO, Husada G. Mucocoele and mucinous tumours of the appendix: A review of the literature. Int J Surg. 2015;18:132-5.

27. Padmanaban V, Morano WF, Gleeson E, Aggarwal A, Mapow BL, Stein DE, et al. Incidentally discorvered lowgrade appendiceal mucinous neoplasm: a precursor to pseudomyxoma peritonei. Clin Case Rep. 2016;4(12):1112-6. 
Table 1. The distribution sex and age groups of appendiceal tumor types.

\begin{tabular}{|c|c|c|c|c|c|}
\hline Sex & $\begin{array}{c}\text { Carcinoid } \\
\text { Tumor }\end{array}$ & $\begin{array}{l}\text { Mixt Carcinoid- } \\
\text { Adenocarcinoma }\end{array}$ & Adenocarcinoma & $\begin{array}{c}\text { Differentiated } \\
\text { Mucinous } \\
\text { Adenocarcinoma }\end{array}$ & $\begin{array}{l}\text { Undifferentiated } \\
\text { Mucinous } \\
\text { Adenocarcinoma }\end{array}$ \\
\hline Male & 2 & 1 & - & - & 2 \\
\hline Female & 5 & - & 1 & 4 & - \\
\hline 0-30 Age & 5 & - & - & - & - \\
\hline 30-60 Age & 2 & - & - & - & 2 \\
\hline $60+$ Age & - & 1 & 1 & 4 & - \\
\hline
\end{tabular}


Table 2. The distribution localization and size of appendiceal tumor types.

\begin{tabular}{|c|c|c|c|c|c|}
\hline $\begin{array}{l}\text { Localization and } \\
\text { Size }\end{array}$ & $\begin{array}{c}\text { Carcinoid } \\
\text { Tumor }\end{array}$ & $\begin{array}{l}\text { Mixt Carcinoid- } \\
\text { Adenocarcinoma }\end{array}$ & Adenocarcinoma & $\begin{array}{c}\text { Differentiated } \\
\text { Mucinous } \\
\text { Adenocarcinoma }\end{array}$ & $\begin{array}{l}\text { Undifferentiated } \\
\text { Mucinous } \\
\text { Adenocarcinoma }\end{array}$ \\
\hline Mucosal layer & 7 & - & - & 1 & 1 \\
\hline Serosal layer & - & - & - & 1 & 1 \\
\hline Mesoappendix & - & 1 & 1 & 2 & - \\
\hline Tumor Size<1cm & 6 & - & - & 1 & 2 \\
\hline Tumor Size $1-2 \mathrm{~cm}$ & 1 & - & - & 1 & - \\
\hline Tumor Size > $2 \mathrm{~cm}$ & - & 1 & 1 & 2 & - \\
\hline
\end{tabular}


Table 3. The distribution performed surgical treatments of appendiceal tumor types.

\begin{tabular}{|c|c|c|c|c|c|}
\hline Treatment & $\begin{array}{c}\text { Carcinoid } \\
\text { Tumor }\end{array}$ & $\begin{array}{l}\text { Mixt Carcinoid- } \\
\text { Adenocarcinoma }\end{array}$ & Adenocarcinoma & $\begin{array}{c}\text { Differentiated } \\
\text { Mucinous } \\
\text { Adenocarcinoma }\end{array}$ & $\begin{array}{l}\text { Undifferentiated } \\
\text { Mucinous } \\
\text { Adenocarcinoma }\end{array}$ \\
\hline $\begin{array}{l}\text { Appendectomy } \\
\text { Primary Operation } \\
\text { Right }\end{array}$ & 7 & 1 & 1 & 4 & 2 \\
\hline $\begin{array}{l}\text { Hemicolectomy } \\
\text { Secondary } \\
\text { Operation } \\
\text { Right }\end{array}$ & - & - & 1 & 2 & - \\
\hline Hemicolectomy & - & 1 & - & 1 & 1 \\
\hline $\mathrm{TAH}+\mathrm{BSO}$ & - & - & 1 & 4 & - \\
\hline $\begin{array}{l}\text { Peritonectomy+ } \\
\text { Omentectomy }\end{array}$ & - & - & 1 & 3 & 1 \\
\hline
\end{tabular}




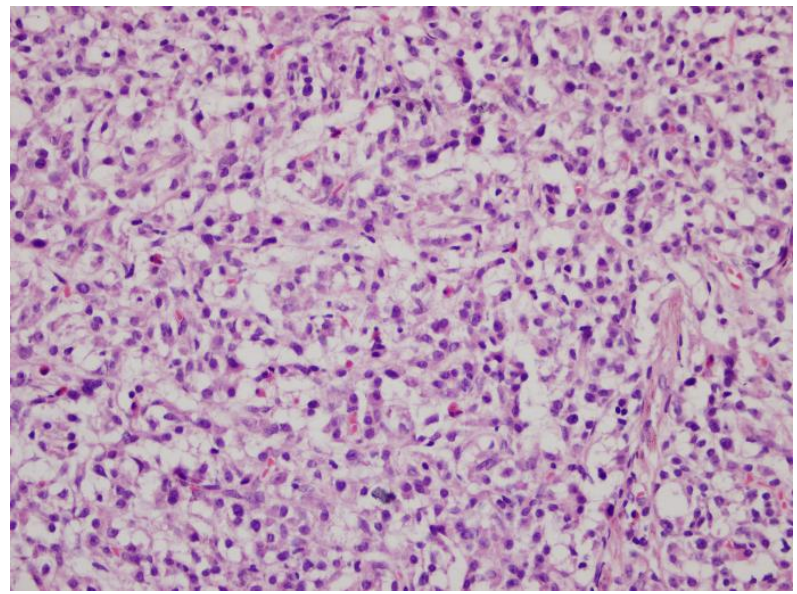

Figure 1A. The tumor composed of monotone cells have slim chromatin structure in case of a large layer (H/E X 40).

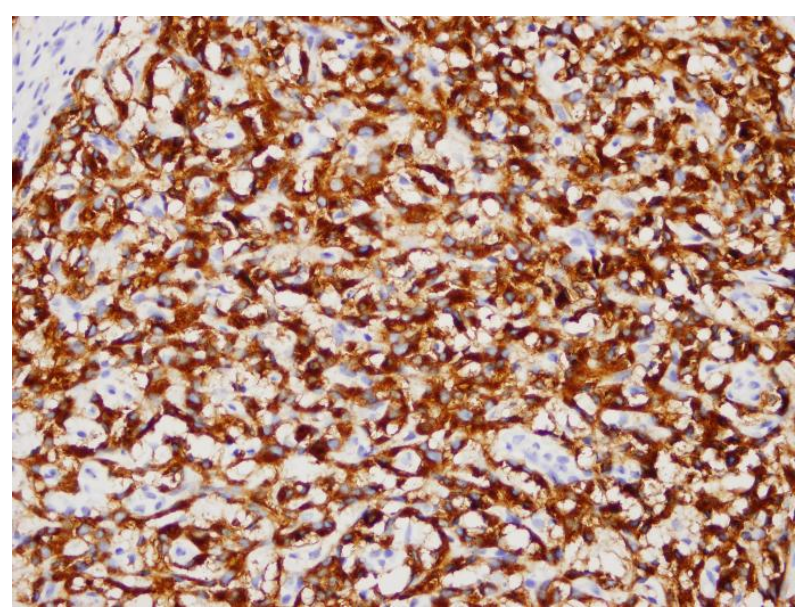

Figure 1B. In synaptophysin immunohistochemical study, tumor cells were stained widespread positively (H/E X 40). 


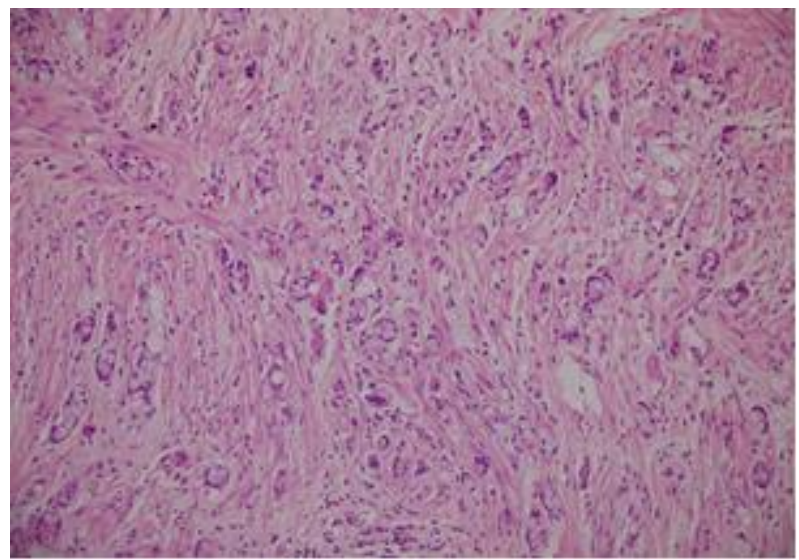

Figure 2A. Mixt carcinoid adenocarcinoma. Tumor infiltration that the majority composed of goblet cells in case of the single cell and small glands into a desmoplastic stroma on appendix wall was seen (H/E X 20).

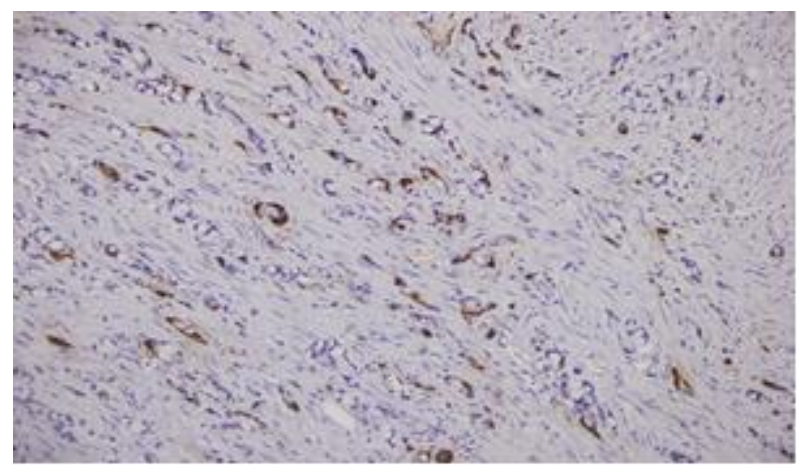

Figure 2B. In chromogranin immunohistochemical study, one part of the cell composed of atypical glands was stained positively (H/E X 20). 


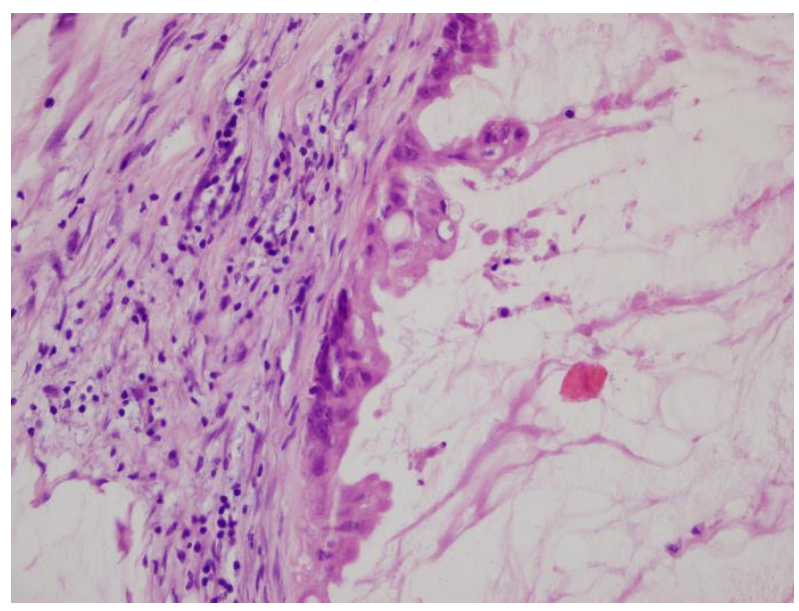

Figure 3. Mucinous carcinoma comprising of atypical cells who showing clear pleomorphism into mucin small lake (H/E X 40). 